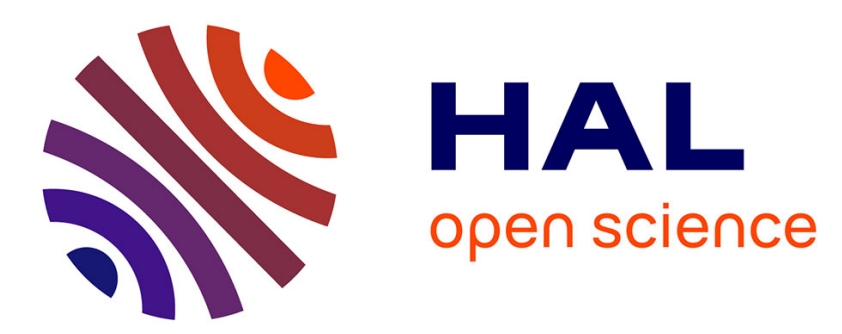

\title{
Toxicity of iron nanoparticles towards primary cultures of human bronchial epithelial cells
}

Ludivine Canivet, Franck-olivier Denayer, P. Dubot, Guillaume Garçon, J.-m. Lo Guidice

\section{- To cite this version:}

Ludivine Canivet, Franck-olivier Denayer, P. Dubot, Guillaume Garçon, J.-m. Lo Guidice. Toxicity of iron nanoparticles towards primary cultures of human bronchial epithelial cells. Journal of Applied Toxicology, 2020, 41 (2), pp.203 - 215. 10.1002/jat.4033 . hal-03411532

\section{HAL Id: hal-03411532 \\ https://hal.science/hal-03411532}

Submitted on 2 Nov 2021

HAL is a multi-disciplinary open access archive for the deposit and dissemination of scientific research documents, whether they are published or not. The documents may come from teaching and research institutions in France or abroad, or from public or private research centers.
L'archive ouverte pluridisciplinaire HAL, est destinée au dépôt et à la diffusion de documents scientifiques de niveau recherche, publiés ou non, émanant des établissements d'enseignement et de recherche français ou étrangers, des laboratoires publics ou privés. 


\title{
Toxicity of iron nanoparticles towards primary cultures of human bronchial epithelial cells
}

\author{
Ludivine Canivet $^{1}$ | Franck-Olivier Denayer ${ }^{1}$ | Pierre Dubot ${ }^{2}$ | \\ Guillaume Garçon $^{1}$ | J.-M. Lo Guidice ${ }^{1}$
}

${ }^{1}$ Univ. Lille, CHU Lille, Institut Pasteur de Lille, ULR 4483-IMPECS-IMPact de

I'Environnement Chimique sur la Santé,

F-59000 Lille, France

${ }^{2}$ CNRS UMR 7182, Métaux et céramiques à microstructure contrôlée, Institut de Chimie et des Matériaux, Paris Est, Thiais, France

\section{Correspondence}

Pr. Guillaume Garçon, Univ. Lille, CHU Lille, Institut Pasteur de Lille, ULR 4483 IMPECSIMPact de l'Environnement Chimique sur la Santé, F-59000, Lille, France.

Email: guillaume.garcon@univ-lille.fr

Funding information

Université de Lille, Conseil Régional du Nord-Pas de Calais (CPER-IRENI); Agence de I'Environnement et de la Maîtrise de l'Energie (ADEME)

\begin{abstract}
Air pollution is a public health issue and the toxicity of ambient particulate matter (PM) is well-recognized. Although it does not mostly contribute to the total mass of $\mathrm{PM}$, increasing evidence indicates that the ultrafine fraction has generally a greater toxicity than the others do. A better knowledge of the underlying mechanisms involved in the pathological disorders related to nanoparticles (NPs) remains essential. Hence, the goal of this study was to determine better whether the exposure to a relatively low dose of well-characterized iron-rich NPs (Fe-NPs) might alter some critical toxicological endpoints in a relevant primary culture model of human bronchial epithelial cells (HBECs). We sought to use Fe-NPs representative of those frequently found in the industrial smokes of metallurgical industries. After having noticed the effective internalization of Fe-NPs, oxidative, inflammatory, DNA repair, and apoptotic endpoints were investigated within HBECs, mainly through transcriptional screening. Taken together, these results revealed that, despite it only produced relatively low levels of reactive oxygen species without any significant oxidative damage, low-dose Fe-NPs quickly significantly deregulated the transcription of some target genes closely involved in the proinflammatory response. Although this inflammatory process seemed to stay under control over time in case of this acute scenario of exposure, the future study of its evolution after a scenario of repeated exposure could be very interesting to evaluate the toxicity of Fe-NPs better.
\end{abstract}

\section{KEYWORDS}

gene expression profiling, human bronchial epithelial cells, inflammation, iron nanoparticles, oxidative stress, physicochemical characterization

\section{1 | INTRODUCTION}

Air pollution still constitutes the major threat to human health, whereas the adverse impacts and the underlying mechanisms of air pollution-derived particulate matter (PM) are not clearly defined (Beelen et al., 2015; Hamra et al., 2014; Jerrett et al., 2017; Raaschou-Nielsen et al., 2016). PM is a mixture of solid and liquid tiny particles of different origins, sizes and compositions. Various classifications and terminologies have been used to define particle size ranges (Terzano, Di Stefano, Conti, Graziani, \& Petroianni, 2010). Generally, particles are divided into three groups, namely, coarse, fine and ultrafine particles (UFP) with aerodynamic diameters within a range between 2.5 and $10 \mu \mathrm{m}\left(\mathrm{PM}_{10-2.5}\right),<2.5 \mu \mathrm{m}\left(\mathrm{PM}_{2.5}\right)$ and $<0.1 \mu \mathrm{m}\left(\mathrm{PM}_{0.1}\right)$, respectively (Chen et al., 2016). Ambient PM is most often characterized by the content of $\mathrm{PM}_{10}$ and $\mathrm{PM}_{2.5}$, as their concentrations are limited by the air quality guidelines of the World Health Organization $\left(20 \mu \mathrm{g} / \mathrm{m}^{3}\right.$ annual mean and $50 \mu \mathrm{g} / \mathrm{m}^{3}$ 24-hour mean for $\mathrm{PM}_{10}$, and $10 \mu \mathrm{g} / \mathrm{m}^{3}$ annual mean and $25 \mu \mathrm{g} / \mathrm{m}^{3}$ 24-hour 
mean for $\mathrm{PM}_{2.5}$ ). The association of pulmonary and cardiovascular adverse health effects with $\mathrm{PM}_{10}$ or $\mathrm{PM}_{2.5}$ ambient levels has been already well-described. Although they do not contribute substantially to total mass of particles, increasing evidence indicates that UFP, particularly those that originated from human activities, may have greater impact on human health than the other larger sized fractions (Kornberg et al., 2017). In contrast to UFP, which are derived from both natural and anthropogenic sources, nanoparticles (NPs), commonly defined as particles having at least one dimension $<100 \mathrm{~nm}$, are prepared deliberately by humans at the nanoscale. Consequently, they exhibit properties that provide technological advantages compared with the bulk form of the same material (Stone et al., 2017). The health effects induced by engineered NPs are similar to those caused by UFP, as inhalation is the most probable and easiest route for nanosized particles to enter into the human body (Stone et al., 2017). The research findings of NPs in nanotoxicology prove that they behave differently from larger inhalable particles, and their chemical constituents, which are nontoxic at the micrometer scale, will become toxic at the nanometer scale (Kornberg et al., 2017). To achieve engineering for safety goals, it is also urgently needed to understand the toxicity of NPs better themselves and recognize that toxicological evaluation is only one part of an overall risk assessment process. However, it is impossible to determine safer exposure levels and safer material designs without having first a better knowledge of dosespecific toxicological effects.

The risk of exposure to NPs is particularly high for people working within the production sites of engineered NPs. NPs made by transition metals are widely used in technology and some of them are known to induce both pro-oxidative and proinflammatory activities (Andersen et al., 2011; Gustafsson, Lindstedt, Elfsmark, \& Bucht, 2011; Jerrett et al., 2017). For instance, fine/micron-sized iron-rich PM (Fe-PM) is incidentally released from a number of industrial processes, including iron ore mining, steel processing, welding and pyrite production (Kornberg et al., 2017). Moreover, Fe-NPs are naturally present in the outdoor atmospheres because they may be emitted from building materials and vehicles, such as cars and train brakes (Gasser et al., 2009; Wilkinson et al., 2012). The use of more efficient air filters in industries allowed to retain the fine but not the ultrafine fraction of emitted PM, the latest still representing an area of toxicology of emerging concern (Stone et al., 2017). During the exposure, NPs mainly penetrate into the body by inhalation, and, after deposition within the lungs, can provoke some severe injuries (e.g., inflammation, bronchial hyper-reactivity, tissue remodeling) and even contaminate the bloodstream (Brandenberger et al., 2010; Oberdörster et al., 2004; Patil et al., 2012; Petitot et al., 2013; Suliman et al., 2015). Indeed, the internalization of different types of NPs into various human lung cell models has already been well-reported (Stone et al., 2017). There is also a number of underlying mechanisms by which NPs may impair cell homeostasis, including the occurrence of oxidative and inflammatory responses (Miller et al., 2013; Nel, Xia, Mädler, \& Li, 2006; Stone et al., 2017). The ability of NPs to induce an overproduction of reactive oxygen species (ROS), either intrinsically or via different cell sources, has been well documented and is frequently associated with other toxic effects (Stone et al., 2017). Although the mechanisms underlying Fe-NP-induced toxicity are still poorly understood, most researchers suggested they are largely due to Fe-induced or catalyzed ROS production (Ghio, Dailey, Richards, \& Jang, 2009). Accordingly, Fe-PM, as wüstite $(\mathrm{FeO})$ and hematite $\left(\mathrm{Fe}_{2} \mathrm{O}_{3}\right)$, has already been shown as inducing redox and inflammatory responses in a set of in vitro and in vivo studies (Garçon et al., 2000; Garçon et al., 2001a, 2001b, 2004a, 2004b). More recent studies supported similar results for Fe-NPs (Bhattacharya et al., 2012; Donaldson et al., 2005; Eom \& Choi, 2009, 2011; Keenan, Goth-Goldstein, Lucas, \& Sedlak, 2009; Kim, Kim, Lee, Oh, \& Chung, 2011). However, these effects are likely to be related to multiple physicochemical characteristics of Fe-NPs and may include other underlying mechanisms of toxicity such as direct physical NP-cell interaction and receptor-mediated activation of specific signaling pathways (Thomassen et al., 2011).

The better knowledge of the underlying mechanisms closely involved in the pathogenesis of lung disorders related to NPs remains essential. Hence, we sought to use an original primary culture model of human bronchial epithelial cells (HBECs) to test the toxicity of a relatively low dose of well-characterized Fe-NPs, representative of those encountered in the industrial smokes of metallurgical industries (Canivet, Denayer, Champion, Cenedese, \& Dubot, 2014). After having verified the effective internalization of Fe-NPs into HBECs, oxidative, inflammatory, DNA repair and apoptotic endpoints were also investigated.

\section{MATERIALS AND METHODS}

\section{1 | Chemicals}

All the culture reagents were provided by LONZA. Sigma-Aldrich provided all the chemical reagents and monoclonal pan-cytokeratin antibody (Clone PCK-26). Promega provided CellTiter-Glo ${ }^{\circledR}$ luminescent cell viability. ThermoFisher Scientific provided Alexa Fluor ${ }^{\mathrm{TM}} 488$ conjugated goat polyclonal antimouse antibody, SlowFade Gold Antifade reagent containing DAPI, 6-carboxy-2',7'-dichlorodihydrofluorescein diacetate (carboxy- $\mathrm{H}_{2}$ DCFDA), Pierce ${ }^{\mathrm{TM}}$ BCA protein assay kits, and all the reagents for molecular biology. Qiagen provided RNeasy mini Kits. Merck-Millipore provided periodic acid-Schiff (PAS) staining kit and MU5AC antibody (mouse monoclonal MAB2011; Clone CLH2).

\section{2 | Iron nanoparticle synthesis and physicochemical characterization}

Metallic iron nanocrystals were produced using a cryogenic melting gas condensation technique as described by Champion and Bigot (1996). Briefly, to avoid contamination through reaction with a crucible, the metal was heated in a radiofrequency levitation furnace. The analytical methods used to determine the physicochemical characteristics of Fe-NPs have been published elsewhere (Canivet et al., 2014). Briefly, the shape and the size of Fe-NPs, at their pristine state or after their suspension in Hanks' balanced salt solution (HBSS) 
or bronchial epithelial cell growth medium, with or with sonication, were determined by scanning electron microscopy (LEO 1530; Zeiss). Their surface charge, chemical composition and specific surface area were determined by dynamic light scattering (Zetasizer I; Malvern Instruments), X-ray photoelectron spectroscopy (K-ALPHA; ThermoScientific), and Brunauer, Emmet and Teller (BET) method by nitrogen adsorption (Micromeritics Type ASAP 2010), respectively.

\subsection{Human bronchial epithelial cell culture and characterization}

HBECs were derived from healthy peripheral bronchial tissues of patients $(n=3)$ undergoing surgery for lung carcinoma, as published elsewhere (Courcot et al., 2012). After surgical resection, macroscopically healthy areas of lobar bronchi were immediately immersed in Dulbecco's modified Eagle's medium supplemented with $1 \%(\mathrm{v} / \mathrm{v})$ penicillin-streptomycin and $2 \%(\mathrm{v} / \mathrm{v})$ fungizone, and then stored at $4^{\circ} \mathrm{C}$ until used. Bronchial segments were rinsed twice with ice-cold phosphate-buffered saline (PBS) and processed for mucosa isolation. Small pieces of bronchial mucosa, approximately $2 \mathrm{~mm}^{2}$, were used as a source of primary cells. They were placed in Petri dishes, precoated with rat tail type I collagen at $0.03 \mathrm{mg} / \mathrm{mL}$ for 30 minutes at $37^{\circ} \mathrm{C}$, in the presence of $5 \mathrm{~mL}$ of a serum-free medium (bronchial epithelial cell growth medium; Lonza) supplemented with $1 \%(\mathrm{v} / \mathrm{v})$ penicillin-streptomycin and $2 \%(\mathrm{v} / \mathrm{v})$ amphotericin B. After an adherence period of 24 hours at $37^{\circ} \mathrm{C}$ and $5 \% \mathrm{CO}_{2}, 5 \mathrm{~mL}$ of supplemented culture medium were added and, thereafter, changed every 2-3 days until epithelial cells grown from bronchial explants reached almost full confluence. After trypsinization, HBECs were gathered, reseeded in six-well plates, 96-wells plates or LabTeck ${ }^{\circledR}$ chamber Slide ${ }^{\text {TM }}$ Systems, precoated with rat tail type I collagen at $0.03 \mathrm{mg} / \mathrm{mL}$ for 30 minutes at $37^{\circ} \mathrm{C}$, and cultured until confluency.

HBECs ground on LabTeck ${ }^{\circledR}$ chamber Slide $^{\mathrm{TM}}$ Systems were fixed with $1 \%(\mathrm{v} / \mathrm{v})$ paraformaldehyde for 3 minutes at $37^{\circ} \mathrm{C}$ and methanol for 5 minutes at $-20^{\circ} \mathrm{C}$. Mucus secretion was identified by PAS reaction using the standard protocol recommended by the manufacturer (PAS staining kit; Merck-Millipore). HBECs were mounted using the Eukitt $^{\circledR}$ quick-hardening mounting medium. For immunofluorescence labeling, HBECs were permeabilized for 3 minutes with PBS containing $0.2 \%(\mathrm{v} / \mathrm{v})$ Triton $\mathrm{X}-100$ and rinsed three times for 5 minutes with PBS. They were incubated for 1 hour at $37^{\circ} \mathrm{C}$ with primary antibodies diluted in 3\% $(\mathrm{v} / \mathrm{v})$ bovine serum albumin, $0.05 \%(\mathrm{v} / \mathrm{v})$ Tween and $0.08 \%(\mathrm{v} / \mathrm{v})$ sodium azide in PBS. MU5AC antibody (mouse monoclonal MAB2011; Clone CLH2; Merck-Millipore) and monoclonal pancytokeratin antibody (Clone PCK-26; Sigma-Aldrich) were respectively diluted at $1 / 250$ and $1 / 100$. After three 5-minute washes in PBS, HBECs were incubated for 30 minutes at $37^{\circ} \mathrm{C}$ with a goat polyclonal antimouse antibody, Alexa Fluor ${ }^{\mathrm{TM}} 488$ conjugate (ThermoFisher Scientific) diluted at $1 / 400$ in $3 \%(v / v)$ bovine serum albumin, $0.05 \%$ $(\mathrm{v} / \mathrm{v})$ Tween and $0.08 \%(\mathrm{v} / \mathrm{v})$ sodium azide in PBS (Leclercq et al., 2016; Sotty et al., 2019). After three 5-minute washes in PBS, HBECs were mounted with the SlowFade Gold Antifade reagent containing DAPI (Life Technologies) and images were acquired on an EVOS $^{\text {TM }}$ FL Cell Imaging System (Life Technologies).

\section{4 | Human bronchial epithelial cell exposure to iron nanoparticles}

Just before cell exposure, culture media were renewed to eliminate death cells, and Fe-NPs were extemporaneously suspended in sterile HBSS (ThermoFisher Scientific) and ultrasonicated (Deltasonic; Somatherm; frequency: $28 \mathrm{kHz}$; power source: $120 \mathrm{~W}$ ) for 5 minutes before their use. According to Kaur et al. (2017), the effective acoustic power delivered to the dispersion in the ultrasonic bath was calculated to be $0.193 \mathrm{~W}$. CellTiter-Glo ${ }^{\circledR}$ luminescent cell viability assay was carried out in HBECs exposed to increasing concentrations of Fe-NPs from 0 to $300 \mu \mathrm{g} / \mathrm{cm}^{2}$ for 24 hours at $37^{\circ} \mathrm{C}$ and $5 \% \mathrm{CO}_{2}$, as recommended by the manufacturer's instructions (Promega). This assay system used the properties of a proprietary thermostable luciferase to enable reaction conditions that generate a stable "glow-type" luminescent signal. The mono-oxygenation of luciferin was catalyzed by luciferase in the presence of $\mathrm{Mg}^{2+}$, ATP and molecular oxygen, and resulted in the emission of light, directly linked to the ATP concentration and the number of living cells. Accordingly, for the further study of the other toxicological endpoints, HBECs were thereafter exposed in triplicate to a final concentration of $2 \mu \mathrm{g} / \mathrm{cm}^{2}$ (or $9.5 \mu \mathrm{g} / \mathrm{mL}$ ) of Fe-NPs for 6, 24 and 48 hours.

\section{5 | Human bronchial epithelial cell observations by transmission electron microscopy}

HBECs exposed for 24 hours at $37^{\circ} \mathrm{C}$ and $5 \% \mathrm{CO}_{2}$ to Fe-NPs at $2 \mu \mathrm{g} / \mathrm{cm}^{2}$ (or $9.5 \mu \mathrm{g} / \mathrm{mL}$ ) were washed twice with PBS, fixed in $0.5 \%$ $(\mathrm{v} / \mathrm{v})$ paraformaldehyde- and $2 \%(\mathrm{v} / \mathrm{v})$ glutaraldehyde-containing PBS for 20 minutes at room temperature, and then overnight at $4^{\circ} \mathrm{C}$ after renewing the fixative solution (Leclercq et al., 2018; Sotty et al., 2019, 2020). After three washes with a solution of $0.22 \mathrm{M}$ sucrose in PBS for 10 minutes, HBECs were post-fixed with $1 \%(\mathrm{~m} / \mathrm{v}) \mathrm{OsO}_{4}$ in PBS for 2 hours at room temperature. Fixed samples were thereafter dehydrated in a series of graded alcohols and embedded in Epon resin. Ultrathin sections (50-90 nm) were cut with an ultramicrotome (Reichert Ultracut E), stained with uranyl acetate and lead citrate, and examined with a Zeiss EM902 transmission electron microscope at $80 \mathrm{kV}$ equipped with the Orius camera interface (Carl Zeiss France SAS). Numerical images were acquired with Gatan Microscopy Suite ${ }^{\circledR}$ software.

\subsection{Reactive oxygen species production and oxidative damage within human bronchial epithelial cells}

To study production of ROS, HBECs were incubated with $20 \mu \mathrm{M}$ carboxy- $\mathrm{H}_{2}$ DCFDA in HBSS (ThermoFisher Scientific) for 1 hour at $37^{\circ} \mathrm{C}$ and $5 \% \mathrm{CO}_{2}$. Thereafter, HBECs were washed with PBS and exposed to Fe-NPs at $2 \mu \mathrm{g} / \mathrm{cm}^{2}$ (or $9.5 \mu \mathrm{g} / \mathrm{mL}$ ), $20 \mu \mathrm{M}$ phorbol ester myristate (Sigma) as positive controls, or $40 \mu \mathrm{M} \mathrm{N}$-acetylcysteine 
(ThermoFisher Scientific) as negative controls. Fluorescence $\left(\lambda_{\text {ex }}\right.$ 492-495 nm; $\lambda_{\text {em }}$ : $517-527 \mathrm{~nm}$ ) was monitored at $37^{\circ} \mathrm{C}$ every 10 minutes for 3 hours with the GloMax ${ }^{\circledR}$-Multi Detection System (Promega). Malondialdehyde (MDA) concentrations were determined in HBECs lysed with $0.1 \%(\mathrm{~m} / \mathrm{v})$ butylated hydroxytoluene ethanolic solution using high-performance liquid chromatography with fluorescence detection, as published by Garçon et al. (2006). Glutathione status (i.e., ratio between oxidized and reduced forms: [GSSG]/[GSH]) was determined in HBECs lysed with $10 \%(\mathrm{v} / \mathrm{v}$ ) cold metaphosphoric acid using high-performance liquid chromatography with fluorescence detection, as published elsewhere (Leclercq et al., 2016, 2017). The total protein quantification was determined using the Pierce ${ }^{\mathrm{TM}}$ BCA Protein Assay Kit (ThermoFisher Scientific) according to the manufacturer's recommendations.

\section{7 | Regulation of gene expression within human bronchial epithelial cells}

Total RNA was extracted from HBECs with the miRNeasy Mini $\mathrm{Kit}^{\mathrm{TM}}$ (Qiagen) according to the manufacturer's instructions. The yield of the extracted RNA was determined by measuring the optical density at $260 \mathrm{~nm}$ with the BioSpec nanospectrophotometer (Shimadzu). After reverse transcription of $1 \mu \mathrm{g}$ of total RNA in single-stranded cDNA using the High Capacity cDNA Reverse Transcription Kit (ThermoFisher Scientific), gene expression relative quantitation was carried out using custom TaqMan ${ }^{\mathrm{TM}}$ Low Density Arrays, a 7900HT Real-Time polymerase chain reaction (PCR) System (ThermoFisher Scientific), and the Expression Suite Software (ThermoFisher Scientific). The set of selected genes comprised target genes encoding proteins involved in oxidative stress regulation (43), inflammatory process (223), DNA repair and apoptosis regulation (72), and other functions (42, including 15 mucin genes) (see Supporting Information). The mRNA expression levels of the 10 genes exhibiting the highest differential expressions after Fe-NP exposure were analyzed in HBECs derived from three independent donors, using reverse transcription-quantitative PCR. PCR amplifications were conducted on the Step one plus thermocycler using $50 \mathrm{ng}$ of reverse transcription products, TaqMan Gene Expression Master Mix $(2 x)$ and specific TaqMan Gene Expression Assays (20x), according to the protocol supplied by the manufacturer (ThermoFisher Scientific). The analysis of gene expression was realized using the RQ Manager 1.3 software (ThermoFisher Scientific).

\section{8 | Statistical analysis}

Normality and equality of variances were checked for each data set. Data were presented as means and standard deviations of triplicate. Each experimental value was compared with that of the corresponding negative control at each time point. When the normality and the equality of variance were checked, one-way analysis of variance was used to examine the difference between Fe-NP exposed- and negative control HBECs. Then, a Dunnett's post hoc test was carried out for pairwise difference, using negative control HBECs. When normality was skewed, a Kruskal-Wallis test was performed (followed by Dunnett's post hoc test). The level of statistical significance was set at $P<.05$. Analyses were performed with SigmaStat ${ }^{\circledR} 2.03$ software (SPSS Inc.).

\section{3 | RESULTS}

\section{1 | Iron nanoparticle physicochemical characteristics}

The physicochemical characterization of the Fe-NPs under study was first performed in their pristine state. As shown in Figure $1 \mathrm{~A}$ and Table 1, Fe-NPs were associated in bundles but have an individual spherical shape with a diameter in the range of 20.0-80.0 nm. Accordingly, BET measurements realized with $\mathrm{N}_{2}$ on Fe-NPs gave a specific surface of $21.72 \pm 0.17 \mathrm{~m}^{2} / \mathrm{g}$. Assuming a density of $7.87 \mathrm{~g} / \mathrm{cm}^{3}$ for iron, Canivet et al. (2014) estimated a mean diameter of $35.1 \mathrm{~nm}$ for the individual spherical Fe-NPs. These Fe-NPs were also representative of industrial smoke emitted by metallurgical industries. They were formed from a metallic iron core with an oxide layer $\left(\mathrm{Fe}^{2+}\right.$ and $\left.\mathrm{Fe}^{3+}\right)$ of $2.1 \mathrm{~nm}$, as revealed by the $\mathrm{Fe}_{2 \mathrm{p}}$ core level. A layer of hydroxide could be shown by deconvolution of the $\mathrm{O}_{1 \mathrm{~s}}$ peak. Fe-NPs were free from any impurity. Fe-NPs were magnetic and formed some agglomerates, with an average size of $700 \mathrm{~nm}$. The sonication of Fe-NP solution reduced their average size to $200 \mathrm{~nm}$. Their zeta potential and surface area at their pristine state were $-12 \mathrm{mV}$ and $21.72 \mathrm{~m}^{2} / \mathrm{g}$, respectively. The volume-specific surface area (VSSA), understood as a surface area related to the volume instead of mass, can constitute an additional criterion independent of the size distribution and the density of the nanomaterial. The VSSA of Fe-NPs $\left(218.27 \mathrm{~m}^{2} / \mathrm{cm}^{3}\right)$ allowed us to state that, even agglomerated, they still had their specific reactivity. Thereafter, Fe-NPs were characterized 24 hours after their suspension in HBSS or in supplemented culture medium. Moreover, like Fe-NPs in their pristine state, Fe-NPs suspended in HBSS and in supplemented culture medium formed some agglomerates with average sizes ranging from 600 to $700 \mathrm{~nm}$. Immersion of Fe-NPs in HBSS only slightly increased the oxide thickness from 0.16 to $2.26 \mathrm{~nm}$, whereas the hydroxylation surface was higher from those at their pristine state. While HBSS slightly interplayed toward Fe-NP oxidation at a day scale, on the contrary, supplemented culture medium strongly interact by increasing the iron oxide layer thickness, up to $2.8 \mathrm{~nm}$ after 24 hours, and up to $3.1 \mathrm{~nm}, 24$ hours later.

\section{2 | Characterization of human bronchial epithelial cells}

PAS staining confirmed the capacity of some of the HBECs to secrete mucus (Figure 1B). Both pan-cytokeratin and MUC5AC protein expression, highly characteristic for HBECs, were specifically detected using immunofluorescence labeling of isolated cells (Figure 1C). 
FIGURE 1 A, Observation of iron-rich nanoparticles in scanning electronic microscopy (magnification $\times 50$ 000). B, Periodic acid-Schiff of human bronchial epithelial cells; fuchsia color corresponds to polysaccharides (magnification $\times 600$ ). C, Fluorescence immunostaining of pan cytokeratin and MUC5AC in human bronchial epithelial cells. Nuclei are revealed in blue with DAPI (magnification $\times 400$ ) [Colour figure can be viewed at wileyonlinelibrary.com]
(A)

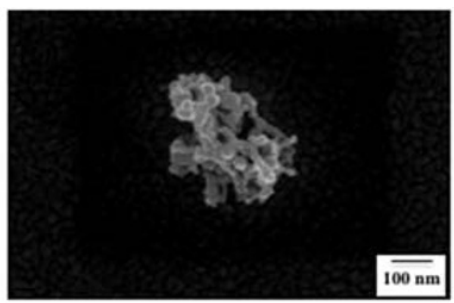

(B)

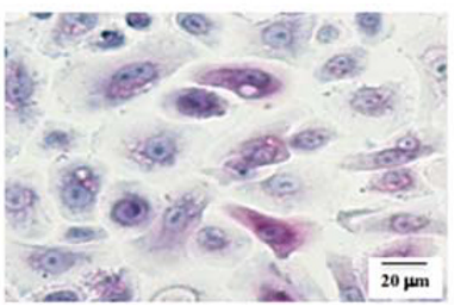

(C)

Cytokeratin

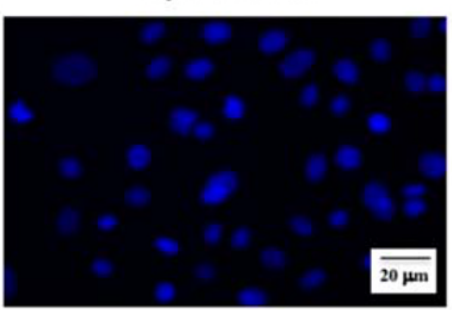

MUC5AC

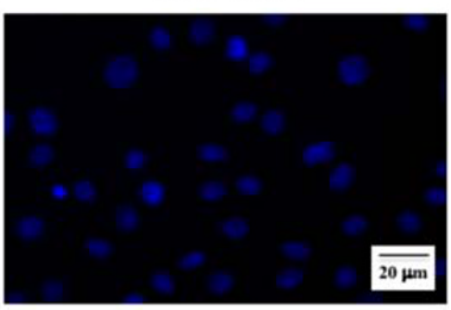

Alexa 488
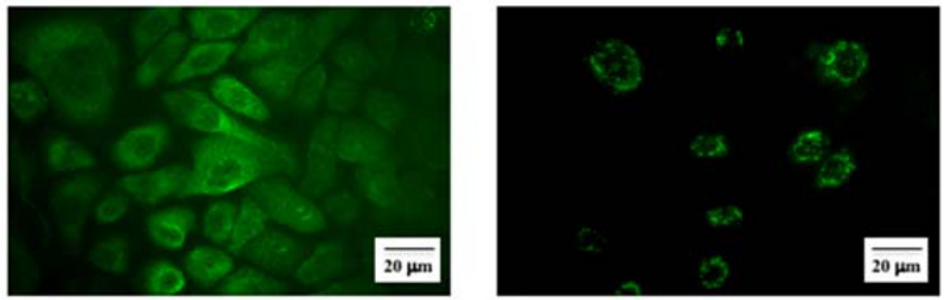

Merge

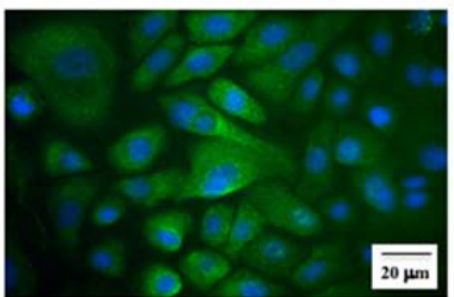

TABLE 1 Physicochemical characteristics of iron-rich nanoparticles in their pristine state

\begin{tabular}{|c|c|c|c|c|c|c|c|}
\hline Shape & Composition & Purity & $\begin{array}{l}\text { Surface } \\
\text { area }\left(\mathrm{m}^{2} / \mathrm{g}\right)\end{array}$ & Size distribution (nm) & Agglomeration (nm) & $\begin{array}{l}\text { Zeta } \\
\text { potential }(\mathrm{mV})\end{array}$ & $\begin{array}{l}\text { VSSA } \\
\left(\mathrm{m}^{2} / \mathrm{cm}^{3}\right)\end{array}$ \\
\hline Sphere & $\begin{array}{c}\text { Core of metallic iron with an } \\
\text { oxide }\left(\mathrm{Fe}^{2+} \text { and } \mathrm{Fe}^{3+}\right) \text { and } \\
\text { hydroxide layer of } 2 \mathrm{~nm}\end{array}$ & $\begin{array}{l}\text { Free of } \\
\text { impurity }\end{array}$ & 21.72 & $20-80$ & $\begin{array}{l}700 \text { (average of } \\
200 \text { with } \\
\text { sonication step) }\end{array}$ & -12 & 218.27 \\
\hline
\end{tabular}

\subsection{Iron nanoparticle internalization by human bronchial epithelial cells}

Figures $2 \mathrm{~A}$ and $2 \mathrm{~B}$ revealed the internalization of Fe-NPs into membrane-bound vesicles, as small aggregates. Fe-NPs entering from the apical surface could form an endosome, which may cross the cell to the basolateral surface and thereafter fuse with the plasma membrane, thereby releasing Fe-NPs into the extracellular fluid on the basolateral side. Both particle aggregation and agglomeration have been shown to play a major role in the severity of Fe-NP-induced adverse outcomes. 


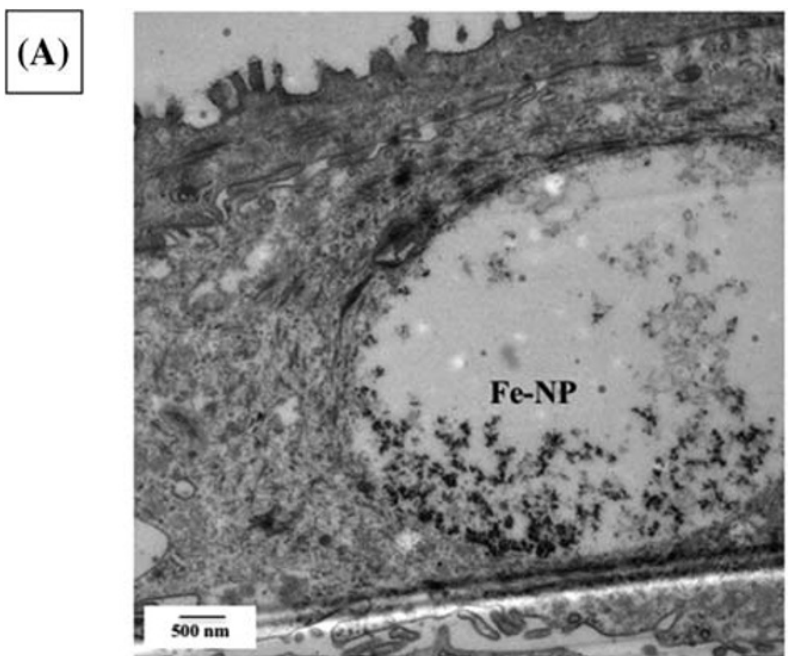

(B)

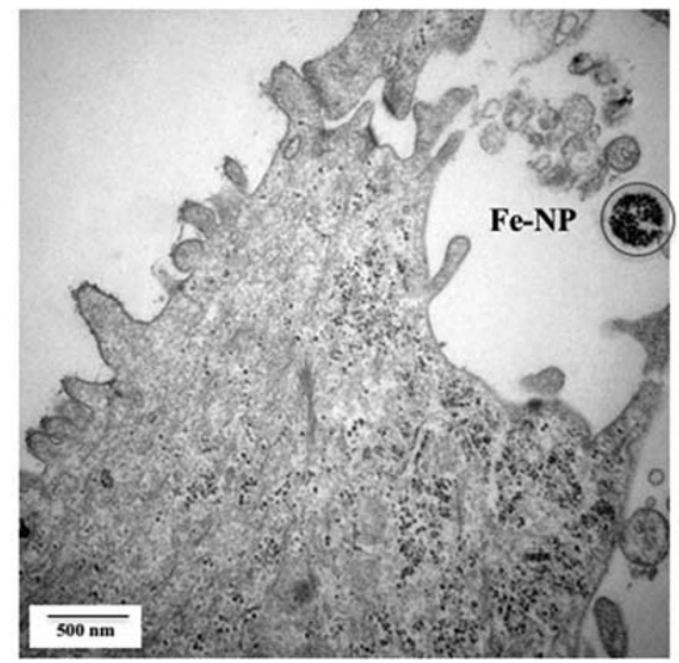

FIGURE 2 A, B, Observations of human bronchial epithelial cells exposed to $2 \mu \mathrm{g} / \mathrm{cm}^{2}$ of Fe-NPs using transmission electronic microscopy. Confirmation of the presence of Fe-NPs, enclosed in vesicles (red circle), within human bronchial epithelial cells $24 \mathrm{~h}$ after their exposure to Fe-NPs. Fe-NPs, iron-rich nanoparticles

\subsection{Cell viability of iron nanoparticle-exposed human bronchial epithelial cells}

The viability was reduced in a dose-dependent manner in HBECs 24 hours after their exposure to increasing concentrations of Fe-NPs, ranging from 0 to $300 \mu \mathrm{g} / \mathrm{cm}^{2}$ (Figure 3). The inhibitory concentration at $10 \%$ (i.e., $2 \mu \mathrm{g} / \mathrm{cm}^{2}$ ) has been chosen to be further applied to study the other toxicological endpoints.

\subsection{Reactive oxygen species production and oxidative damage in iron nanoparticle-exposed human bronchial epithelial cells}

No significant difference of intracellular ROS production was observed between Fe-NP-exposed and negative control HBECs

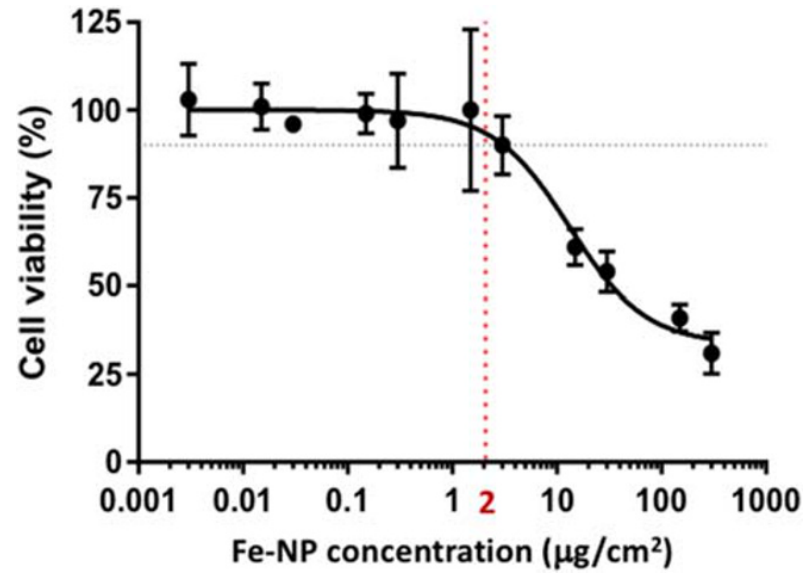

FIGURE 3 Cell viability, assessed through intracellular adenosine triphophosphate concentrations of human bronchial epithelial cells exposed for $24 \mathrm{~h}$ to increasing concentration of Fe-NPs. Calculated inhibitory concentration at $10 \%\left(\mathrm{IC}_{10}\right)$ corresponded to $2 \mu \mathrm{g} / \mathrm{cm}^{2}$. Results are expressed as the means \pm SD of three independent experiments conducted in triplicate $(n=9)$. Fe-NPs, iron-rich nanoparticles [Colour figure can be viewed at wileyonlinelibrary.com]

(Figure 4A). Time-dependent continuous increases of intracellular ROS levels were reported for both exposed and negative control HBECs. In this work, to study the possible consequences of Fe-NPinduced ROS production, glutathione status ([GSSG]/[GSH]) and MDA levels were assessed (Figure $4 B$ and $4 C$, respectively). However, HBEC exposure to the low-dose Fe-NPs for 6, 24 and 48 hours did not induce any significant modification of glutathione status nor MDA production, despite slight increases.

\subsection{Modulation of gene expression within human bronchial epithelial cells}

Venn diagrams showed the expression patterns of differentially regulated genes (DRGs; upregulated: relative quantity [RQ] $\geq 2$ or downregulated: RQ $\leq 0.5)$ within Fe-NP-exposed vs. control HBECs (Figure $5 \mathrm{~A}$ and $5 \mathrm{~B}$ ). Most of them were involved in oxidative stress, inflammation, DNA repair, apoptosis and mucin secretion regulation (see also Table S1; see Supporting Information). Overall, there is a time-dependent decrease of the number of DRGs in Fe-NP-exposed HBECs: after 6 hours, 46 and 32 DRGs were up- and downregulated whereas after 48 hours, only one and four genes were up- and downregulated, respectively. Among the genes deregulated after 6 and 24 hours of exposure: nine genes were upregulated (i.e., CXCR4, interleukin (IL)13RA2, MMP1, IL24, IL17D, FGFR1, MUC13, IL18, IL1R2) and eight genes were downregulated (i.e., TNFSF10, CCR10, TLR1, TLR3, IL7, TLR6, TNFSF11, CXCR2). Then, after 6 and 48 hours of exposure, three genes were upregulated (i.e., FGF1, LTA, NOS3) and only four genes downregulated (i.e., CXCL10, BAX, IL27, GPR156). In addition, as shown in Figure S1 and Table S1 (see Supporting Information), among all the DRGs, 55 target DRGs were highly up- or downregulated as they displayed at least 


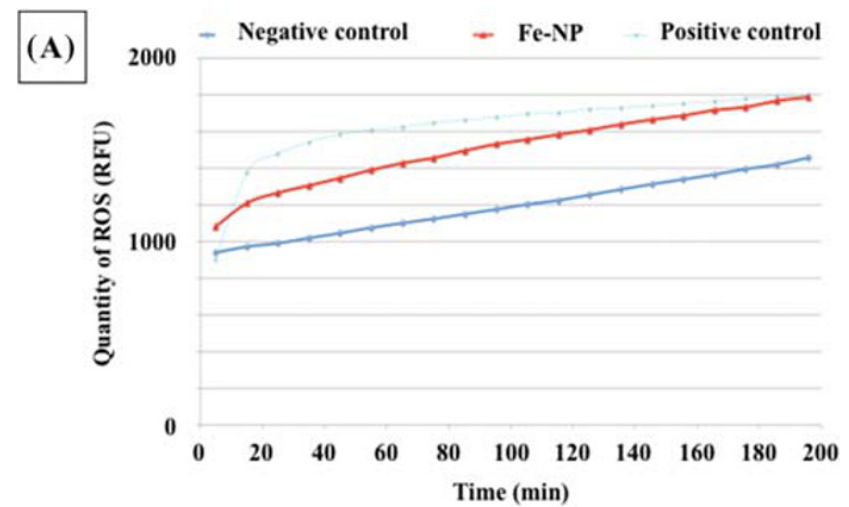

(B)

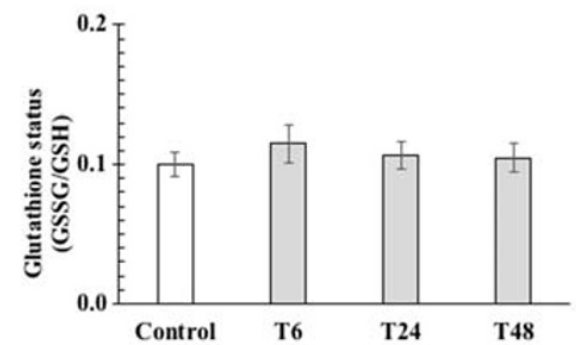

(C)

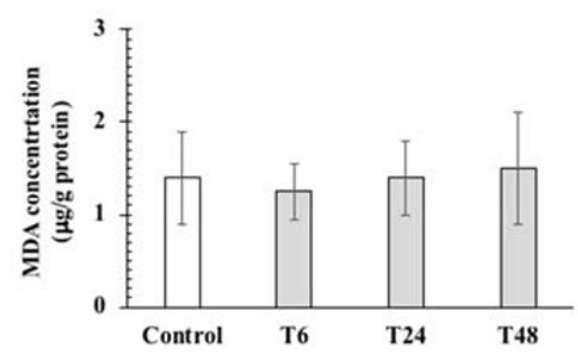

FIGURE 4 A, Intracellular ROS production in HBECs exposed to $2 \mu \mathrm{g} / \mathrm{cm}^{2}$ of Fe-NPs. HBECs incubated with $40 \mathrm{mM} \mathrm{N}$-acetylcysteine or $20 \mu \mathrm{M}$ phorbol ester myristate served as negative and positive controls, respectively. Results are expressed as the mean \pm SD of three independent experiments conducted in triplicate $(n=9)$. Kruskal-Wallis test with Dunnett's post hoc test with $t=5 \mathrm{~min}$ as reference to see the evolution over time $\left({ }^{*} P<.05\right)$. B, C, Glutathione status (i.e., ratio between [GSSG]/[GSH] and MDA concentrations ( $\mu \mathrm{g} / \mathrm{g}$ of protein) in HBECs exposed to $2 \mu \mathrm{g} / \mathrm{cm}^{2}$ of Fe-NPs. Values are depicted as mean and SD $(n=3)$. Results are expressed as the means \pm SD of three independent experiments conducted in triplicate $(n=9)$. One-way ANOVA with Dunnett's post hoc test, ${ }^{*} P<.05$. Fe-NPs, iron-rich nanoparticles; [GSSG]/[GSH], ratio between oxidized and reduced form of glutathione; HBECs, human bronchial epithelial cells; MDA, malondialdehyde; ROS, reactive oxygen species; T6, 6 h of exposure; T24, 24 h of exposure; T48, $48 \mathrm{~h}$ of exposure [Colour figure can be viewed at wileyonlinelibrary.com]

a fourfold difference in their transcript levels ( $R Q \geq 4$ or $R Q \leq 0.25$ ) in Fe-NP-exposed HBECs. Notably, the highest number of highly DRGs was reported 6 hours after exposure to HBECs. Thereafter, among them, a set of 10 DRGs was carefully selected: the eight genes exhibiting the highest changes after Fe-NP exposure (i.e., four upregulated genes: MMP3, IL13RA1, MMP1, CSF2 and four downregulated genes: GRP156, TNFSF11, CCR10, CASP5), and IL8 and PTGS2 for their known implication in inflammation processes. The
(A)

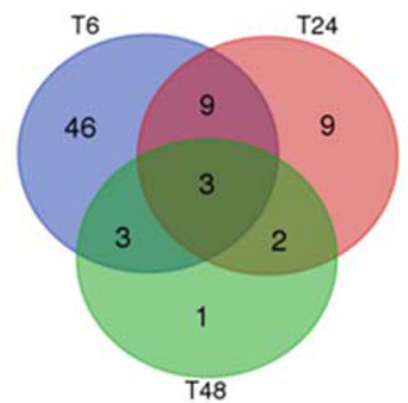

\begin{tabular}{|c|c|c|}
\hline Names & Total & Dements \\
\hline กลT46 T6 & 3 & CSZ NQPNLITA \\
\hline T24T6 & ? & 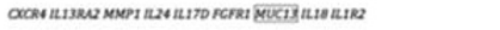 \\
\hline Tละ T6 & 3 & FCH LTA SOSB \\
\hline 72474 & 2 & (NELL) CDNO \\
\hline T6 & 46 & 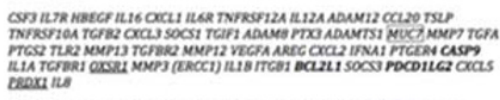 \\
\hline 724 & 9 & 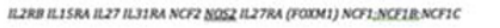 \\
\hline T48 & 1 & (Bacil) \\
\hline
\end{tabular}

(B)

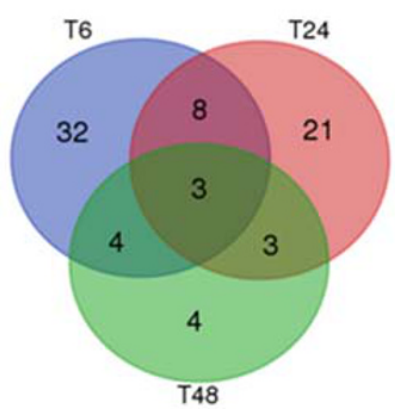

\begin{tabular}{|c|c|c|}
\hline Names & Total & Dements \\
\hline 724 T46 T6 & 3 & Cusps sciert saxz \\
\hline 72476 & s & 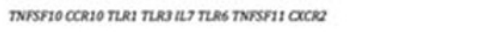 \\
\hline T48 T6 & 4 & 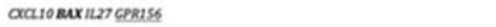 \\
\hline T24 T48 & $\mathbf{3}$ & 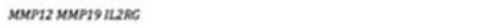 \\
\hline T6 & 32 & 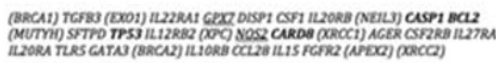 \\
\hline$n 24$ & 21 & 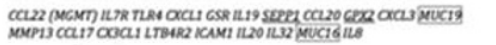 \\
\hline 748 & 4 & INF MMPS MUCIB COFIR \\
\hline
\end{tabular}

FIGURE 5 A, Venn diagram representing the expression pattern of upregulated genes $(R Q>2, P<.05)$ in human bronchial epithelial cells exposed to $2 \mu \mathrm{g} / \mathrm{cm}^{2}$ of iron-rich nanoparticles. B, Venn diagram representing the expression pattern of downregulated genes (RQ $<0.5, P<.05)$ in human bronchial epithelial cells exposed to $2 \mu \mathrm{g} / \mathrm{cm}^{2}$ of iron-rich nanoparticles (vs. negative controls). RQ, relative quantity; T6, $6 \mathrm{~h}$ of exposure; T24, $24 \mathrm{~h}$ of exposure; T48, $48 \mathrm{~h}$ of exposure) [Colour figure can be viewed at wileyonlinelibrary.com]

Fe-NP-induced changes previously reported for all these 10 target genes were confirmed in three independent cell cultures (Table 2). Accordingly, a time-dependent decrease of the number of DRGs was reported in Fe-NP-exposed cells: after 6 hours, six (i.e., IL8, IL13RA2, CSF2, PTGS2, MMP3, MMP1) and one (i.e., TNFSF11) DRG were 
TABLE 2 Relative quantities of the 10 selected target gene expressions in human bronchial epithelial cells exposed to $2 \mu \mathrm{g} / \mathrm{cm}^{2}$ of iron-rich nanoparticles for 6, 24 and $48 \mathrm{~h}$

\begin{tabular}{|llll|} 
& \multicolumn{2}{l}{ Relative quantity } & \\
\cline { 2 - 4 } Gene name & $6 \mathrm{~h}$ & $24 \mathrm{~h}$ & $48 \mathrm{~h}$ \\
\hline TNFSF11 & $0.35^{*}$ & 0.50 & 0.67 \\
\hline CASP5 & 0.63 & 0.62 & 0.67 \\
\hline GPR156 & 0.80 & 0.94 & 0.63 \\
\hline CCR10 & 0.99 & 1.64 & 1.06 \\
\hline IL8 & 2.73 & 1.01 & 1.02 \\
\hline IL13RA2 & $3.56^{*}$ & 2.42 & 1.09 \\
\hline CSF2 & 3.74 & 2.46 & 1.66 \\
\hline PTGS2 & $4.44^{*}$ & 1.57 & 1.25 \\
\hline MMP3 & $9.38^{*}$ & 1.39 & 0.85 \\
\hline MMP1 & $9.79^{*}$ & 3.90 & 1.05 \\
\hline
\end{tabular}

respectively up- and downregulated, whereas after 48 hours, no DRGs were reported. After 6 hours, four (i.e., IL13RA2, PTGS2, MMP1, MMP3) and one (i.e., TNFSF11) DRG were significantly up- and downregulated, respectively, whereas none were significantly deregulated after 24 and 48 hours.

\section{4 | DISCUSSION}

Despite intensive effort during the last decades, there is still a lack of information on NPs in environmental science and human health studies. Interestingly, toxicological studies have shown that nanosized particles possessed quite different physicochemical properties than the fine fraction, such as lower mass, higher reactivity and higher surface area to mass ratio, thereby usually posing more serious adverse effects on human health than larger sized particles (Stone et al., 2017). A thorough knowledge of NPs, including the issues of sources, composition and size distribution is essential for the assessment of the potential health risks and will contribute to the identification of related toxicological effects (Chen et al., 2016). In this study, we investigated the toxicity induced by well-characterized Fe-NPs in HBECs.

The Fe-NPs under study were representative of those emitted by metal industries (Canivet et al., 2014). At their pristine state, Fe-NPs were spherical and ranged from 20 to $80 \mathrm{~nm}$. Assuming a density of $7.87 \mathrm{~g} / \mathrm{cm}^{3}$ for iron, Canivet et al. (2014) estimated a mean diameter of $35.1 \mathrm{~nm}$ for the individual spherical Fe-NPs. They were formed from a metallic iron core with an oxide layer $\left(\mathrm{Fe}^{2+}\right.$ and $\left.\mathrm{Fe}^{3+}\right)$ of $2.1 \mathrm{~nm}$, with a layer of hydroxide. Fe-NPs were free from any impurity. Fe-NPs were magnetic and formed some agglomerates, with an average size of $700 \mathrm{~nm}$; their sonication reduced their average size to $200 \mathrm{~nm}$. The VSSA of Fe-NPs $\left(218.27 \mathrm{~m}^{2} / \mathrm{cm}^{3}\right)$ was allowed to state that, even agglomerated, they still had their specific reactivity. Kreyling, Semmler-Behnke and Chaudhry (2010) noted that NPs with VSSA above $60 \mathrm{~m}^{2} / \mathrm{cm}^{3}$ are characterized by an average size below $100 \mathrm{~nm}$, thereby indicating a high nanomaterial or nanostructure content. Thereafter, Fe-NPs were characterized 24 hours after their suspension in HBSS or in supplemented culture medium. Their surface oxidation was in agreement with those reported by Bhattacharya et al. (2009). He et al. (2008) noted that Fe-containing NPs tend to agglomerate when suspended in a low $\mathrm{pH}$ solution, the increase of the agglomerate size being directly proportional to their initial size. Kumar et al. (2007) noticed biomolecule adsorption on the surface of Fe-containing NPs, which altered their zeta potential and provoked their agglomeration. While HBSS slightly interplayed toward Fe-NP oxidation at a day scale, on the contrary, supplemented culture medium strongly interact by increasing the iron oxide layer thickness. According to Canivet et al. (2014), immersion of Fe-NPs in HBSS or supplemented culture medium led to the formation of an oxyhydroxide layer containing chlorinated species. The initial passivated surface oxide layer, mainly $\mathrm{Fe}_{2} \mathrm{O}_{3}$ is thus transformed into a thicker oxyhydroxide layer that has a greater ability to adsorb molecular ions or ionic biomolecules such as proteins or DNA. More soluble iron compounds are formed on the NP surface that could be more easily dissolved after exposition to the intracellular medium. Accordingly, modifications of Fe-NP surface chemistry due to supplemented culture medium can act on cell cytotoxicity both by direct molecular adsorption due to a higher surface affinity to biomolecules or by the induced oxyhydroxide dissolution, which releases toxic iron ions.

Thereafter, to contribute to a better knowledge of the underlying mechanisms involved in Fe-NP toxicity, a relevant primary culture model of HBECs was used. The isolation procedure from healthy peripheral bronchial tissues of patients undergoing surgery for lung carcinomas ensure that they exhibited a phenotype very similar to this observed in vivo (Bérubé, Prytherch, Job, \& Hughes, 2010; Boublil et al., 2013; Leclercq et al., 2016, 2017; Leclercq et al., 2018; Pezzulo et al., 2011; Sotty et al., 2019). Accordingly, PAS staining confirmed the capacity of some of them to secrete mucus, whereas, pancytokeratin and MUC5AC protein expression, highly characteristic for epithelia and bronchial cells, respectively, were specifically detected using immunofluorescence labeling of HBECs. Bhowmick and GappaFahlenkamp (2016) showed that HBECs displayed the highest similarities with bronchial mucosa in terms of transcript profiling and seemed to be one of the most relevant in vitro models for studying the toxicity of inhaled NPs.

According to Bhattacharya et al. $(2009,2012)$ and Könczöl et al. (2011), Fe-NPs were internalized into membrane-bound vesicles, as small aggregates. Fe-NPs entering from the apical surface could form an endosome, which may cross the cell to the basolateral surface and fuse with the plasma membrane, thereby releasing Fe-NPs into the extracellular fluid on the basolateral side. Particle aggregation and agglomeration have been shown to play a major role in the severity of Fe-NP-induced adverse outcomes. As mentioned by Kornberg et al. (2017), it is generally accepted that smaller-sized particles are able to induce more toxicity on a per mass basis due to increases of both surface area and particle number. However, if NPs are agglomerated, their adverse outcomes may be different, because they will be recognized by the cells as a larger-sized structure. However, to date, the mechanisms involved in the absorption of Fe-NPs are not well- 
identified. Four pathways are described for endocytosis of NPs: caveolar-mediated endocytosis dependent upon clathrin, phagocytosis, micropinocytosis and pinocytosis (Forman \& Finch, 2018). Only few studies used HBECs to investigate NP toxicity (Åkerlund et al., 2018; Ekstrand-Hammarström et al., 2013; Herzog et al., 2009; Herzog et al., 2009; Zhang et al., 2011). Most studies have also been conducted using lung cell lines such as immortalized HBECs: BEAS-2B (Ekstrand-Hammarström et al., 2012; Eom \& Choi, 2011; Gilbert et al., 2012) and 16HBE cells (Belade et al., 2012; Keenan et al., 2009; Otero-González, Sierra-Alvarez, Boitano, \& Field, 2012) or cancerderived cell lines: A549 (Choi, Oh, \& Choy, 2009; Khan et al., 2012). Hence, many apparently contradicting results have been reported due to the use of different cell types and the test of a variable range of concentrations (Liu, Gao, Ai, \& Chen, 2013).

The inhibitory concentration at $10 \%$ (i.e., $2 \mu \mathrm{g} / \mathrm{cm}^{2}$ ) has been chosen to be further applied to study the other toxicological endpoints. This concentration is among the lowest used in the literature. It is always very important to reduce particle exposure as much as possible to keep a sufficient dose to study the underlying mechanisms of action while contributing to the effort to be as close as possible to human exposure levels (Leclercq et al., 2016). In exposed Balb/c mice by whole body inhalation to $\mathrm{Fe}_{3} \mathrm{O}_{4} \mathrm{NPs}$ (i.e., $19.9 \mathrm{mg} / \mathrm{m}^{3}$ over 4 hours), Teeguarden et al. (2014) reported target tissue doses in the bronchial (about $1 \mu \mathrm{g} / \mathrm{cm}^{2}$ ) and the alveolar $\left(0.003-0.13 \mu \mathrm{g} / \mathrm{cm}^{2}\right.$ ) regions. The Fe-NP dose of $2 \mu \mathrm{g} / \mathrm{cm}^{2}$ we applied on to HBECs was also in the same order of magnitude as that deposited in the bronchial region of this in vivo model.

Over time, exposure to Fe-NPs only produced a relatively low levels of ROS without any significant oxidative damage, as carried out by glutathione status ([GSSG]/[GSH]) and MDA production. Feng et al. (2018), who exposed human ovarian cancer SKOV-3 cells and murine RAW 264.7 macrophages to relatively high concentrations of various Fe-containing NPs, noticed time-dependent intracellular ROS production. Liu et al. (2013) indicated that the most toxicities from Fe-containing NPs derived from ROS overproduction, which can thereafter damage cells by peroxidizing lipids, injuring DNA and proteins, modulating gene transcription, and altering the physiological function and regulated cell death. However, in this work, the relatively low ROS production induced by the low-dose Fe-NPs applied on to HBECs seemed not able to overwhelm the antioxidant defenses nor the repair capacities of HBECs (Garçon et al., 2000, 2001b, 2006). Bhattacharya et al. (2009) showed that a same dose of Fe-containing NPs $\left(\mathrm{Fe}_{2} \mathrm{O}_{3}, 50 \mathrm{~nm}\right)$, also roughly comparable with this used by Teeguarden et al. (2014), induced an almost similar decrease in cell viability but higher ROS production in human bronchial fibroblasts. Dwivedi et al. (2014) showed that a low dose of Fe-containing NPs $\left(\mathrm{Fe}_{3} \mathrm{O}_{4}, 174 \mathrm{~nm}\right.$ agglomerate) induced a decrease of cell viability and oxidative damage, including lipid peroxidation and glutathione oxidation, in cancer-derived A549 cells. The apparent discrepancy between the data arising from the current literature and the original data from this work might rely on the use of different Fe-containing NPs, with their own physicochemical characteristics, and the use of different cell models, primary vs. transformed cells, from different target human lung tissues. This closely reinforced the importance of using a relevant in vitro model, which could also help to reflect the normal human bronchial epithelium better.

To the best of our current knowledge, the studies dealing with the effect of Fe-containing NPs on DRG in the lungs are limited (Arenz, Hellweg, Stojicic, Baumstark-Khan, \& Grotheer, 2006; Brandenberger et al., 2010; Foldbjerg et al., 2012; Monteiller et al., 2007; Park, Choi, Park, \& Park, 2008). Hence, to go further ahead, DRG profiles of a set of selected target genes encoding proteins closely involved in oxidative stress, inflammation, DNA repair, apoptosis and other mechanisms such as mucus secretion were studied. Accordingly, oxidative stress, inflammation and cell cycle deregulation were among the main adverse cell outcomes reported as activated by a single short-term exposure of lung cells to Fecontaining NPs (Chen et al., 2016; Huang, Cambre, \& Lee, 2017; Kornberg et al., 2017; Loxham et al., 2015; Stone et al., 2017). Indeed, IL-8 was first described as a chemoattractant cytokine, which plays an important physiological role in the biology of leukocytes and other cell types by controlling tissue homeostasis, cell recruitment and activation and guiding leukocyte movements under basal and inflammatory state mediators (Russo, Garcia, Teixeira, \& Amaral,2014). IL-13RA2 is a receptor for IL-13, which is a major inducer of fibrosis in many chronic infectious and autoimmune diseases (Fichtner-Feigl, Strober, Kawakami, Puri, \& Kitani, 2006). Described primarily as a decoy, IL-13RA2 acts as a scavenger receptor, a potent antagonist of IL-13 activity in epithelial cells, and would be a potentially critical mediator of IL-13 clearance in humans (Kasaian et al., 2013). Granulocyte macrophage-colony stimulating factor (granulocyte macrophage-CSF), also known as CSF2, is an important survival, proliferation and differentiation factor of the progenitor cells for neutrophils and macrophages (Park et al., 2015). Shoeb et al. (2017), studying the toxicity of a complex welding-generated aerosol of incidental NPs and metals, such as Fe, in RAW264.7 cells, indicated elevated expression of prostaglandin-endoperoxide synthase 2 (PTGS2), also known as cyclooxygenase 2 (COX-2), thereby corroborating the development of a proinflammatory response. Cheng et al. (2012) showed dose- and time-dependent increases of PTGS2 in 1,2 naphthoquinone-exposed BEAS-2B cells whereas Ahn et al. (2008) demonstrated its significant increases, at both transcriptional and protein levels, in DEP-treated cells. In addition to proteolytic degradation of the lung parenchyma, matrix metalloproteinase (MMP)-associated activity also participates in a number of other processes, including the inflammatory response, mucus hypersecretion, vascular apoptosis/proliferation and profibrotic pathways (Navratilova, Kolek, \& Petrek, 2016). During inflammation, proprotein MMP are activated through a cascade of proteolytic cleavage to yield active MMP that in turn activate cytokines (e.g., IL-8) and/or modify the binding interaction between some chemokines and their receptors (Foley et al., 2012, 2014). Lindner et al. (2012) noted alterations of MMP1 and MMP3 gene expression in lung cells under proinflammatory conditions. Even if there are only very few studies in lung cells about the possible role of TNFSF11 gene, also called the receptor activator of nuclear factor- $\mathrm{kB}$ ligand (RANKL), an increasing body of evidence suggested that this receptor and its ligand play a 
role in apoptosis (Rao, Cronin, Sigl, \& Penninger, 2018; Sigl, Jones, \& Penninger, 2016). A decrease of TNFSF11 expression could also decrease the activation of anti-apoptotic protein, as a mechanism of defense towards HBEC exposure to Fe-NPs (De Castro et al., 2015). Taken together, the regulation of all these target genes in HBECs in response to their exposure to relatively low doses of Fe-NPs suggested a rapid activation of proinflammatory processes, without a clear ROS overproduction.

In this work, aiming to contribute to a better knowledge of the underlying mechanisms involved in the pathogenicity of lung disorders related to Fe-NPs, we developed a relevant primary culture model of HBECs to test the toxicity of well-characterized Fe-NPs generally typifying Fe-rich NPs emitted by metal industries. Applying this relatively low dose of Fe-NPs on to HBECs allowed us to obtain results that would be most representative for the deposited in vivo dose. HBECs were also able to produce relatively low levels of ROS, without evident oxidative damage, but to regulate quickly the transcription of some target genes closely involved in the proinflammatory response. Although this inflammatory process seemed to stay under control over time, in the case of this acute scenario of exposure, the future study of its evolution after a scenario of repeated exposure could be very interesting to evaluate the toxicity of Fe-NPs better.

\section{ACKNOWLEDGEMENTS}

This work was supported by the Universite de Lille and the Conseil Régional du Nord-Pas de Calais (CPER-IRENI). The Agence de I'Environnement et de la Maîtrise de l'Energie (ADEME) is acknowledged for its financial support (PhD grant of Ludivine CANIVET). We would like to thank Anne Loyens from the "Plateforme de Microscopie Electronique. Imagerie Cellulaire, Tissulaire et Moléculaire" from the INSERM UMR837 JPARC (Lille) for her skilful assistance in cell observations by transmission electron microscopy.

\section{CONFLICT OF INTEREST}

The authors have no conflict of interest to report.

\section{REFERENCES}

Ahn, E.-K., Yoon, H.-K., Jee, B. K., Ko, H.-J., Lee, K.-H., Kim, H. J., \& Lim, Y. (2008). COX-2 expression and inflammatory effects by diesel exhaust particles in vitro and in vivo. Toxicology Letters, 176(3), 178-187. https://doi.org/10.1016/j.toxlet.2007.11.005

Åkerlund, E., Cappellini, F., Di Bucchianico, S., Islam, S., Skoglund, S., Derr, R., \& Karlsson, H. L. (2018). Genotoxic and mutagenic properties of $\mathrm{Ni}$ and $\mathrm{NiO}$ nanoparticles investigated by comet assay, $\gamma-\mathrm{H} 2 \mathrm{AX}$ staining, Hprt mutation assay and ToxTracker reporter cell lines. Environmental and Molecular Mutagenesis, 59(3), 211-222. https://doi.org/ 10.1002/em.22163

Andersen, Z. J., Hvidberg, M., Jensen, S. S., Ketzel, M., Loft, S., Sørensen, M., \& Raaschou-Nielsen, O. (2011). Chronic obstructive pulmonary disease and long-term exposure to traffic-related air pollution: $A$ cohort study. American Journal of Respiratory and Critical Care Medicine, 183(4), 455-461. https://doi.org/10.1164/rccm.201006-09370C

Arenz, A., Hellweg, C. E., Stojicic, N., Baumstark-Khan, C., \& Grotheer, H.-H. (2006). Gene expression modulation in A549 human lung cells in response to combustion-generated nano-sized particles.
Annals of the New York Academy of Sciences, 1091, 170-183. https:// doi.org/10.1196/annals.1378.064

Beelen, R., Hoek, G., Raaschou-Nielsen, O., Stafoggia, M., Andersen, Z. J., Weinmayr, G., \& Brunekreef, B. (2015). Natural-cause mortality and long-term exposure to particle components: An analysis of 19 European cohorts within the multi-center ESCAPE project. Environmental Health Perspectives, 123(6), 525-533. https://doi.org/10.1289/ehp. 1408095

Belade, E., Armand, L., Martinon, L., Kheuang, L., Fleury-Feith, J., Baeza-Squiban, A., \& Boczkowski, J. (2012). A comparative transmission electron microscopy study of titanium dioxide and carbon black nanoparticles uptake in human lung epithelial and fibroblast cell lines. Toxicology in Vitro: An International Journal Published in Association with BIBRA, 26(1), 57-66. https://doi.org/10.1016/j.tiv.2011.10.010

Bérubé, K., Prytherch, Z., Job, C., \& Hughes, T. (2010). Human primary bronchial lung cell constructs: The new respiratory models. Toxicology, 278(3), 311-318. https://doi.org/10.1016/j.tox.2010.04.004

Bhattacharya, K., Davoren, M., Boertz, J., Schins, R. P., Hoffmann, E., \& Dopp, E. (2009). Titanium dioxide nanoparticles induce oxidative stress and DNA-adduct formation but not DNA-breakage in human lung cells. Particle and Fibre Toxicology, 6(17), 1-11. https://doi.org/10. 1186/1743-8977-6-17

Bhowmick, R., \& Gappa-Fahlenkamp, H (2016). Cells and Culture Systems Used to Model the Small Airway Epithelium. Lung, 194(3), 419-428. https://doi:10.1007/s00408-016-9875-2

Bhattacharya, K., Hoffmann, E., Schins, R. F. P., Boertz, J., Prantl, E.-M., Alink, G. M., \& Dopp, E. (2012). Comparison of micro- and nanoscale $\mathrm{Fe}^{+3}$-containing (Hematite) particles for their toxicological properties in human lung cells in vitro. Toxicological Sciences: An Official Journal of the Society of Toxicology, 126(1), 173-182. https://doi.org/10.1093/ toxsci/kfs014

Boublil, L., Assémat, E., Borot, M. C., Boland, S., Martinon, L., Sciare, J., \& Baeza-Squiban, A. (2013). Development of a repeated exposure protocol of human bronchial epithelium in vitro to study the long-term effects of atmospheric particles. Toxicology In Vitro, 27, 533-542. https://doi.org/10.1016/j.tiv.2012.11.008

Brandenberger, C., Rothen-Rutishauser, B., Mühlfeld, C., Schmid, O., Ferron, G. A., Maier, K. L., \& Lenz, A.-G. (2010). Effects and uptake of gold nanoparticles deposited at the air-liquid interface of a human epithelial airway model. Toxicology and Applied Pharmacology, 242(1), 56-65. https://doi.org/10.1016/j.taap.2009.09.014

Canivet, L., Denayer, F. O., Champion, Y., Cenedese, P., \& Dubot, P. (2014). Photoemission study of metallic iron nanoparticles surface aging in biological fluids. Influence on biomolecules adsorption. Applied Surface Science, 307, 272-279. https://doi.org/10.1016/j.apsusc. 2014.04.024

Champion, Y., \& Bigot, J. (1996). Preparation and characterization of nanocrystalline copper powders. Scripta Materialia, 35(4), 517-522. https:// doi.org/10.1016/1359-6462(96)00170-4

Chen, R., Hu, B., Liu, Y., Xu, J., Yang, G., Xu, D., \& Chen, C. (2016). Beyond PM2.5: The role of ultrafine particles on adverse health effects of air pollution. Biochimica et Biophysica Acta, 1860(12), 2844-2855. https://doi.org/10.1016/j.bbagen.2016.03.019

Cheng, W.-Y., Currier, J., Bromberg, P. A., Silbajoris, R., Simmons, S. O., \& Samet, J. M. (2012). Linking oxidative events to inflammatory and adaptive gene expression induced by exposure to an organic particulate matter component. Environmental Health Perspectives, 120(2), 267-274. https://doi.org/10.1289/ehp.1104055

Choi, S.-J., Oh, J.-M., \& Choy, J.-H. (2009). Toxicological effects of inorganic nanoparticles on human lung cancer A549 cells. Journal of Inorganic Biochemistry, 103(3), 463-471. https://doi.org/10.1016/j. jinorgbio.2008.12.017

Courcot, E., Leclerc, J., Lafitte, J.-J., Mensier, E., Jaillard, S., Gosset, P., \& Lo-Guidice, J.-M. (2012). Xenobiotic metabolism and disposition in human lung cell models: Comparison with in vivo expression profiles. 
Drug Metabolism and Disposition: The Biological Fate of Chemicals, 40 (10), 1953-1965. https://doi.org/10.1124/dmd.112.046896

De Castro, J., García, R., Garrido, P., Isla, D., Massuti, B., Blanca, B., \& Vázquez, J. (2015). Therapeutic potential of denosumab in patients with lung cancer: Beyond prevention of skeletal complications. Clinical Lung Cancer, 16(6), 431-446. https://doi.org/10.1016/j.cllc.2015. 06.004

Donaldson, K., Tran, L., Jimenez, L. A., Duffin, R., Newby, D. E., Mills, N., \& Stone, V. (2005). Combustion-derived nanoparticles: A review of their toxicology following inhalation exposure. Particle and Fibre Toxicology, 2(10), 1-14. https://doi.org/10.1186/1743-8977-2-10

Dwivedi, S., Siddiqui, M. A., Farshori, N. N., Ahamed, M., Musarrat, J., \& Al-Khedhairy, A. A. (2014). Synthesis, characterization and toxicological evaluation of iron oxide nanoparticles in human lung alveolar epithelial cells. Colloids and Surfaces. B, Biointerfaces, 122, 209-215. https://doi.org/10.1016/j.colsurfb.2014.06.064

Ekstrand-Hammarström, B., Akfur, C. M., Andersson, P. O., Lejon, C., Osterlund, L., \& Bucht, A. (2012). Human primary bronchial epithelial cells respond differently to titanium dioxide nanoparticles than the lung epithelial cell lines A549 and BEAS-2B. Nanotoxicology, 6(6), 623-634. https://doi.org/10.3109/17435390.2011.598245

Ekstrand-Hammarström, B., Magnusson, R., Österlund, C., Andersson, B. M., Bucht, A., \& Wingfors, H. (2013). Oxidative stress and cytokine expression in respiratory epithelial cells exposed to well-characterized aerosols from Kabul, Afghanistan. Toxicology In Vitro, 27(2), 825-833. https://doi. org/10.1016/j.tiv.2012.12.022

Eom, H.-J., \& Choi, J. (2009). Oxidative stress of silica nanoparticles in human bronchial epithelial cell, Beas-2B. Toxicology in Vitro: An International Journal Published in Association with BIBRA, 23(7), 1326-1332. https://doi.org/10.1016/j.tiv.2009.07.010

Eom, H.-J., \& Choi, J. (2011). $\mathrm{SiO}_{2}$ nanoparticles induced cytotoxicity by oxidative stress in human bronchial epithelial cell, Beas-2B. Environmental Health and Toxicology, 26, 1-7, e2011013. https://doi.org/10. 5620/eht.2011.26.e2011013

Feng, Q., Liu, Y., Huang, J., Chen, K., Huang, J., \& Xiao, K. (2018). Uptake, distribution, clearance, and toxicity of iron oxide nanoparticles with different sizes and coatings. Scientific Reports, 8(2082), 1-13. https:// doi.org/10.1038/s41598-018-19628-z

Fichtner-Feigl, S., Strober, W., Kawakami, K., Puri, R. K., \& Kitani, A. (2006). IL-13 signaling through the IL-13alpha2 receptor is involved in induction of TGF-beta1 production and fibrosis. Nature Medicine, 12 (1), 99-106. https://doi.org/10.1038/nm1332

Foldbjerg, R., Irving, E. S., Hayashi, Y., Sutherland, D. S., Thorsen, K., Autrup, H., \& Beer, C. (2012). Global gene expression profiling of human lung epithelial cells after exposure to nanosilver. Toxicological Sciences: An Official Journal of the Society of Toxicology, 130(1), 145-157. https://doi.org/10.1093/toxsci/kfs225

Foley, C. J., Fanjul-Fernández, M., Bohm, A., Nguyen, N., Agarwal, A., Austin, K., \& Kuliopulos, A. (2014). Matrix metalloprotease 1a deficiency suppresses tumor growth and angiogenesis. Oncogene, 33(17), 2264-2272. https://doi.org/10.1038/onc.2013.157

Foley, C. J., Luo, C., O'Callaghan, K., Hinds, P. W., Covic, L., \& Kuliopulos, A. (2012). Matrix metalloprotease-1a promotes tumorigenesis and metastasis. The Journal of Biological Chemistry, 287(29), 24330-24338. https://doi.org/10.1074/jbc.M112.356303

Forman, H. J., \& Finch, C. E. (2018). A critical review of assays for hazardous components of air pollution. Free Radical Biology \& Medicine, 117, 202-217. https://doi.org/10.1016/j.freeradbiomed.2018.01.030

Garçon, G., Dagher, Z., Zerimech, F., Ledoux, F., Courcot, D., Aboukais, A., \& Shirali, P. (2006). Dunkerque City air pollution particulate matter-induced cytotoxicity, oxidative stress and inflammation in human epithelial lung cells (L132) in culture. Toxicology in Vitro: An International Journal Published in Association with BIBRA, 20(4), 519-528. https://doi.org/10.1016/ j.tiv.2005.09.012
Garçon, G., Zerimech, F., Hannothiaux, M.-H., Gosset, P., Martin, A., Marez, T., \& Shirali, P. (2001a). Antioxidant defense disruption by polycyclic aromatic hydrocarbons-coated onto $\mathrm{Fe}_{2} \mathrm{O}_{3}$ particles in human lung cells (A549). Toxicology, 166(3), 129-137. https://doi.org/10. 1016/S0300-483X(01)00461-9

Garçon, G., Garry, S., Gosset, P., Zerimech, F., Martin, A., Hannothiaux, M.-H., \& Shirali, P. (2001b). Benzo(a)pyrene-coated onto $\mathrm{Fe}_{2} \mathrm{O}_{3}$ particles-induced lung tissue injury: Role of free radicals. Cancer Letters, 167(1), 7-15. https://doi.org/10.1016/S0304-3835(01) 00474-8

Garçon, G., Gosset, P., Zerimech, F., Grave-Descampiaux, B., \& Shirali, P. (2004a). Effect of $\mathrm{Fe}_{2} \mathrm{O}_{3}$ on the capacity of benzo(a)pyrene to induce polycyclic aromatic hydrocarbon-metabolizing enzymes in the respiratory tract of Sprague-Dawley rats. Toxicology Letters, 150(2), 179-189. https://doi.org/10.1016/j.toxlet.2004.01.005

Garçon, G., Gosset, P., Maunit, B., Zerimech, F., Creusy, C., Muller, J.-F., \& Shirali, P. (2004b). Influence of iron $\left({ }^{56} \mathrm{Fe}_{2} \mathrm{O}_{3}\right.$ or $\left.{ }^{54} \mathrm{Fe}_{2} \mathrm{O}_{3}\right)$ in the upregulation of cytochrome P4501A1 by benzo[a]pyrene in the respiratory tract of Sprague-Dawley rats. Journal of Applied Toxicology, 24 (3), 249-256. https://doi.org/10.1002/jat.979

Garçon, G., Shirali, P., Garry, S., Fontaine, M., Zerimech, F., Martin, A., \& Hannothiaux, M.-H. (2000). Polycyclic aromatic hydrocarbon coated onto $\mathrm{Fe}_{2} \mathrm{O}_{3}$ particles: Assessment of cellular membrane damage and antioxidant system disruption in human epithelial lung cells (L132) in culture. Toxicology Letters, 117(1), 25-35. https://doi.org/10.1016/ S0378-4274(00)00231-9

Gasser, M., Riediker, M., Mueller, L., Perrenoud, A., Blank, F., Gehr, P., \& Rothen-Rutishauser, B. (2009). Toxic effects of brake wear particles on epithelial lung cells in vitro. Particle and Fibre Toxicology, 6(30), 1-13. https://doi.org/10.1186/1743-8977-6-30

Ghio, A. J., Dailey, L. A., Richards, J. H., \& Jang, M. (2009). Acid and organic aerosol coatings on magnetic nanoparticles increase iron concentrations in human airway epithelial cells. Inhalation Toxicology, 21(8), 659-667. https://doi.org/10.1080/08958370802406282

Gilbert, B., Fakra, S. C., Xia, T., Pokhrel, S., Mädler, L., \& Nel, A. E. (2012). The fate of $\mathrm{ZnO}$ nanoparticles administered to human bronchial epithelial cells. ACS Nano, 6(6), 4921-4930. https://doi.org/10.1021/ nn300425a

Gustafsson, Å., Lindstedt, E., Elfsmark, L. S., \& Bucht, A. (2011). Lung exposure of titanium dioxide nanoparticles induces innate immune activation and long-lasting lymphocyte response in the Dark Agouti rat. Journal of Immunotoxicology, 8(2), 111-121. https://doi.org/10.3109/ 1547691X.2010.546382

He, J. Q., Shumansky, K., Connett, J. E., Anthonisen, N. R., Paté, P. D., \& Sandford, A. J. (2008). Association of genetic variations in the CSF2 and CSF3 genes with lung function in smoking-induced COPD.. Eur Respir J, 32(1), 25-34. https://doi:10.1183/09031936.00040307

Hamra, G. B., Guha, N., Cohen, A., Laden, F., Raaschou-Nielsen, O., Samet, J. M., \& Loomis, D. (2014). Outdoor particulate matter exposure and lung cancer: A systematic review and meta-analysis. Environmental Health Perspectives, 122, 906-911. https://doi.org/10.1289/ ehp.1408092

Herzog, E., Byrne, H. J., Casey, A., Davoren, M., Lenz, A.-G., Maier, K. L., \& Oostingh, G. J. (2009). SWCNT suppress inflammatory mediator responses in human lung epithelium in vitro. Toxicology and Applied Pharmacology, 234(3), 378-390. https://doi.org/10.1016/j.taap.2008. 10.015

Herzog, E., Byrne, H. J., Davoren, M., Casey, A., Duschl, A., \& Oostingh, G. J. (2009). Dispersion medium modulates oxidative stress response of human lung epithelial cells upon exposure to carbon nanomaterial samples. Toxicology and Applied Pharmacology, 236(3), 276-281. https://doi.org/10.1016/j.taap.2009.02.007

Huang, Y.-W., Cambre, M., \& Lee, H.-J. (2017). The toxicity of nanoparticles depends on multiple molecular and physicochemical 
mechanisms. International Journal of Molecular Sciences, 18(2702), 1-13. https://doi.org/10.3390/ijms18122702

Jerrett, M., Turner, M. C., Beckerman, B. S., Pope, C. A., van Donkelaar, A., Martin, R. V., \& Burnett, R. T. (2017). Comparing the health effects of ambient particulate matter estimated using ground-based versus remote sensing exposure estimates. Environmental Health Perspectives, 125(4), 552-559. https://doi.org/10.1289/EHP575

Kasaian, M. T., Marquette, K., Fish, S., DeClercq, C., Agostinelli, R., Cook, T. A., \& Tchistiakova, L. (2013). An IL-4/IL-13 dual antagonist reduces lung inflammation, airway hyperresponsiveness, and IgE production in mice. American Journal of Respiratory Cell and Molecular Biology, 49(1), 37-46. https://doi.org/10.1165/rcmb. 2012-05000C

Kaur, I., Ellis, L. J., Romer, I., Tantra, R., Carriere, M., Allard, S., ... Valsami-Jones, E. (2017). Dispersion of nanomaterials in aqueous media: towards protocol optimization. Journal of Visualized Experiments, 130, 1-23. https://www.jove.com/video/56074

Keenan, C. R., Goth-Goldstein, R., Lucas, D., \& Sedlak, D. L. (2009). Oxidative stress induced by zero-valent iron nanoparticles and Fe (II) in human bronchial epithelial cells. Environmental Science \& Technology, 43(12), 4555-4560. https://doi.org/10.1021/es9006383

Khan, M. I., Mohammad, A., Patil, G., Naqvi, S. A. H., Chauhan, L. K. S., \& Ahmad, I. (2012). Induction of ROS, mitochondrial damage and autophagy in lung epithelial cancer cells by iron oxide nanoparticles. Biomaterials, 33(5), 1477-1488. https://doi.org/10.1016/j.biomaterials. 2011.10.080

Kim, H. R., Kim, M. J., Lee, S. Y., Oh, S. M., \& Chung, K. H. (2011). Genotoxic effects of silver nanoparticles stimulated by oxidative stress in human normal bronchial epithelial (BEAS-2B) cells. Mutation Research, 726(2), 129-135. https://doi.org/10.1016/j.mrgentox.2011.08.008

Könczöl, M., Ebeling, S., Goldenberg, E., Treude, F., Gminski, R., Gieré, R., \& Mersch-Sundermann, V. (2011). Cytotoxicity and genotoxicity of size-fractionated iron oxide (magnetite) in A549 human lung epithelial cells: Role of ROS, JNK, and NF-кB. Chemical Research in Toxicology, 24(9), 1460-1475. https://doi.org/10.1021/tx200051s

Kornberg, T. G., Stueckle, T. A., Antonini, J. A., Rojanasakul, Y., Castranova, V., Yang, Y., \& Wang, L. (2017). Potential toxicity and underlying mechanisms associated with pulmonary exposure to iron oxide nanoparticles: Conflicting literature and unclear risk. Nanomaterials (Basel, Switzerland), 7(307), 1-26, 307. https://doi.org/ 10.3390/nano7100307

Kreyling, W. G., Semmler-Behnke, M., \& Chaudhry, Q. (2010). A complementary definition of nanomaterial. Nano Today, 5(3), 165-168. https://doi.org/10.1016/j.nantod.2010.03.004

Kumar, A., Sahoo, B., Montpetit, A., Behera, S., Lockey, R. F., \& Mohapatra, S. S. (2007). Development of hyaluronic acid- $\mathrm{Fe}_{2} \mathrm{O}_{3}$ hybrid magnetic nanoparticles for targeted delivery of peptides. Nanomedicine: Nanotechnology, Biology, and Medicine, 3(2), 132-137. https://doi.org/10.1016/j.nano.2007.03.001

Leclercq, B., Happillon, M., Antherieu, S., Hardy, E. M., Alleman, L. Y., Grova, N., \& Garçon, G. (2016). Differential responses of healthy and chronic obstructive pulmonary diseased human bronchial epithelial cells repeatedly exposed to air pollution-derived $\mathrm{PM}_{4}$. Environmental Pollution (Barking, Essex: 1987), 218, 1074-1088. https://doi.org/10. 1016/j.envpol.2016.08.059

Leclercq, B., Kluza, J., Antherieu, S., Sotty, J., Alleman, L. Y., Perdrix, E., \& Garçon, G. (2018). Air pollution-derived $\mathrm{PM}_{2.5}$ impairs mitochondrial function in healthy and chronic obstructive pulmonary diseased human bronchial epithelial cells. Environmental Pollution (Barking, Essex: 1987), 243(Pt B), 1434-1449. https://doi.org/10.1016/j.envpol.2018. 09.062

Leclercq, B., Platel, A., Antherieu, S., Alleman, L. Y., Hardy, E. M., Perdrix, E., \& Garçon, G. (2017). Genetic and epigenetic alterations in normal and sensitive COPD-diseased human bronchial epithelial cells repeatedly exposed to air pollution-derived $\mathrm{PM}_{2.5}$. Environmental
Pollution (Barking, Essex: 1987), 230, 163-177. https://doi.org/10. 1016/j.envpol.2017.06.028

Lindner, D., Zietsch, C., Becher, P. M., Schulze, K., Schultheiss, H.-P., Tschöpe, C., \& Westermann, D. (2012). Differential expression of matrix metalloproteases in human fibroblasts with different origins. Biochemistry Research International, 2012, 875742-875710. https:// doi.org/10.1155/2012/875742

Liu, G., Gao, J., Ai, H., \& Chen, X. (2013). Applications and potential toxicity of magnetic iron oxide nanoparticles. Small (Weinheim an Der Bergstrasse, Germany), 9(9-10), 1533-1545. https://doi.org/10.1002/ smll.201201531

Loxham, M., Morgan-Walsh, R. J., Cooper, M. J., Blume, C., Swindle, E. J., Dennison, P. W., \& Davies, D. E. (2015). The effects on bronchial epithelial mucociliary cultures of coarse, fine, and ultrafine particulate matter from an underground railway station. Toxicological Sciences: An Official Journal of the Society of Toxicology, 145(1), 98-107. https://doi. org/10.1093/toxsci/kfv034

Miller, M. R., McLean, S. G., Duffin, R., Lawal, A. O., Araujo, J. A., Shaw, C. A., \& Hadoke, P. W. F. (2013). Diesel exhaust particulate increases the size and complexity of lesions in atherosclerotic mice. Particle and Fibre Toxicology, 10(61), 1-12. https://doi.org/10.1186/ 1743-8977-10-61

Monteiller, C., Tran, L., MacNee, W., Faux, S., Jones, A., Miller, B., \& Donaldson, K. (2007). The pro-inflammatory effects of low-toxicity low-solubility particles, nanoparticles and fine particles, on epithelial cells in vitro: The role of surface area. Occupational and Environmental Medicine, 64(9), 609-615. https://doi.org/10.1136/oem.2005.024802

Navratilova, Z., Kolek, V., \& Petrek, M. (2016). Matrix metalloproteinases and their inhibitors in chronic obstructive pulmonary disease. Archivum Immunologiae et Therapiae Experimentalis, 64(3), 177-193. https://doi. org/10.1007/s00005-015-0375-5

Nel, A., Xia, T., Mädler, L., \& Li, N. (2006). Toxic potential of materials at the nanolevel. Science (New York, N.Y.), 311(5761), 622-627. https:// doi.org/10.1126/science.1114397

Oberdörster, G., Sharp, Z., Atudorei, V., Elder, A., Gelein, R., Kreyling, W., \& Cox, C. (2004). Translocation of inhaled ultrafine particles to the brain. Inhalation Toxicology, 16(6-7), 437-445. https://doi. org/10.1080/08958370490439597

Otero-González, L., Sierra-Alvarez, R., Boitano, S., \& Field, J. A. (2012). Application and validation of an impedance-based real time cell analyzer to measure the toxicity of nanoparticles impacting human bronchial epithelial cells. Environmental Science \& Technology, 46(18), 10271-10278. https://doi.org/10.1021/es301599f

Park, E-J., Choi, J., Park, Y-K., \& Park, K. (2008). Oxidative stress induced by cerium oxide nanoparticles in cultured BEAS-2B cells.. Toxicology, 245, 90-100. https://doi.org/10.1016/j.tox.2007.12.022

Park, E.-J., Oh, S. Y., Lee, S. J., Lee, K., Kim, Y., Lee, B.-S., \& Kim, J. S. (2015). Chronic pulmonary accumulation of iron oxide nanoparticles induced Th1-type immune response stimulating the function of antigen-presenting cells. Environmental Research, 143(Pt A), 138-147. https://doi.org/10.1016/j.envres.2015.09.030

Patil, G., Khan, M. I., Patel, D. K., Sultana, S., Prasad, R., \& Ahmad, I. (2012). Evaluation of cytotoxic, oxidative stress, proinflammatory and genotoxic responses of micro- and nano-particles of dolomite on human lung epithelial cells A(549). Environmental Toxicology and Pharmacology, 34(2), 436-445. https://doi.org/10.1016/j.etap.2012.05.014

Petitot, F., Lestaevel, P., Tourlonias, E., Mazzucco, C., Jacquinot, S., Dhieux, B., \& Dublineau, I. (2013). Inhalation of uranium nanoparticles: Respiratory tract deposition and translocation to secondary target organs in rats. Toxicology Letters, 217(3), 217-225. https://doi.org/10. 1016/j.toxlet.2012.12.022

Pezzulo, A. A., Starner, T. D., Scheetz, T. E., Traver, G. L., Tilley, A. E., Harvey, B.-G., \& Zabner, J. (2011). The air-liquid interface and use of primary cell cultures are important to recapitulate the transcriptional profile of in vivo airway epithelia. American Journal of Physiology. Lung 
Cellular and Molecular Physiology, 300(1), L25-L31. https://doi.org/10. 1152/ajplung.00256.2010

Raaschou-Nielsen, O., Beelen, R., Wang, M., Hoek, G., Andersen, Z. J., Hoffmann, B., \& Vineis, P. (2016). Particulate matter air pollution components and risk for lung cancer. Environment International, 87, 66-73. https://doi.org/10.1016/j.envint.2015.11.007

Rao, S., Cronin, S. J. F., Sigl, V., \& Penninger, J. M. (2018). RANKL and RANK: From mammalian physiology to cancer treatment. Trends in Cell Biology, 28(3), 213-223. https://doi.org/10.1016/j.tcb.2017.11.001

Russo, R. C., Garcia, C. C., Teixeira, M. M., \& Amaral, F. A. (2014). The CXCL8/IL-8 chemokine family and its receptors in inflammatory diseases. Expert Review of Clinical Immunology, 10(5), 593-619. https:// doi.org/10.1586/1744666X.2014.894886

Shoeb, M., Kodali, V., Farris, B., Bishop, L. M., Meighan, T., Salmen, R., \& Antonini, J. M. (2017). Evaluation of the molecular mechanisms associated with cytotoxicity and inflammation after pulmonary exposure to different metal-rich welding particles. Nanotoxicology, 11(6), 725-736. https://doi.org/10.1080/17435390.2017.1349200

Sigl, V., Jones, L. P., \& Penninger, J. M. (2016). RANKL/RANK: From bone loss to the prevention of breast cancer. Open Biology, 6(160230), 1-9. https://doi.org/10.1098/rsob.160230

Sotty, J., Garçon, G., Denayer, F.-O., Alleman, L.-Y., Saleh, Y., Perdrix, E., \& Canivet, L. (2019). Toxicological effects of ambient fine $\left(\mathrm{PM}_{2.5-0.18}\right)$ and ultrafine $\left(\mathrm{PM}_{0.18}\right)$ particles in healthy and diseased 3D organo-typic mucocilary-phenotype models. Environmental Research, 176(108358), 1-16, 108538. https://doi.org/10.1016/j.envres.2019.108538

Sotty, J., Kluza, J., De Soussa, C., Tardivel, M., Anthérieu, S., Alleman, L. Y., ... Lo Guidice, J.-M. (2020). Mitochondrial alterations triggered by repeated exposure to fine (PM 2.5-0.18) and quasi-ultrafine (PM 0.18) fractions of ambient particulate matter. Environ Int., 142(105830), 1-15. https://doi:10.1016/j.envint.2020.105830

Stone, V., Miller, M. R., Clift, M. J. D., Elder, A., Mills, N. L., Møller, P., \& Cassee, F. R. (2017). Nanomaterials versus ambient ultrafine particles: An opportunity to exchange toxicology knowledge. Environmental Health Perspectives, 125(106002), 1-17. https://doi.org/10.1289/ EHP424

Suliman, Y. A. O., Ali, D., Alarifi, S., Harrath, A. H., Mansour, L., \& Alwasel, S. H. (2015). Evaluation of cytotoxic, oxidative stress, proinflammatory and genotoxic effect of silver nanoparticles in human lung epithelial cells. Environmental Toxicology, 30(2), 149-160. https:// doi.org/10.1002/tox.21880

Teeguarden, J. G., Mikheev, V. B., Minard, K. R., Forsythe, W. C., Wang, W., Sharma, G., \& Thrall, B. D. (2014). Comparative iron oxide nanoparticle cellular dosimetry and response in mice by the inhalation and liquid cell culture exposure routes. Particle and Fibre Toxicology, 11 (46), 1-18. https://doi.org/10.1186/s12989-014-0046-4

Terzano, C., Di Stefano, F., Conti, V., Graziani, E., \& Petroianni, A. (2010). Air pollution ultrafine particles: Toxicity beyond the lung. European Review for Medical and Pharmacological Sciences, 14(10), 809-821.

Thomassen, L. C. J., Rabolli, V., Masschaele, K., Alberto, G., Tomatis, M., Ghiazza, M., \& Fubini, B. (2011). Model system to study the influence of aggregation on the hemolytic potential of silica nanoparticles. Chemical Research in Toxicology, 24(11), 1869-1875. https://doi.org/ 10.1021/tx2002178

Wilkinson, K., Ekstrand-Hammarström, B., Ahlinder, L., Guldevall, K., Pazik, R., Kępiński, L., \& Kessler, V. G. (2012). Visualization of customtailored iron oxide nanoparticles chemistry, uptake, and toxicity. Nanoscale, 4(23), 7383-7393. https://doi.org/10.1039/c2nr32572a

Zhang, H., Xia, T., Meng, H., Xue, M., George, S., Ji, Z., \& Nel, A. E. (2011). Differential expression of syndecan-1 mediates cationic nanoparticle toxicity in undifferentiated versus differentiated normal human bronchial epithelial cells. ACS Nano, 5(4), 2756-2769. https://doi.org/ $10.1021 / \mathrm{nn} 200328 \mathrm{~m}$

VSSA, volume-specific surface area.

\section{SUPPORTING INFORMATION}

Additional supporting information may be found online in the Supporting Information section at the end of this article.

How to cite this article: Canivet L, Denayer F-O, Dubot P, Garçon G, Lo Guidice J-M. Toxicity of iron nanoparticles towards primary cultures of human bronchial epithelial cells. J Appl Toxicol. 2020;1-13. https://doi.org/10.1002/jat.4033 